\title{
TARKASTELUSSA IÄKKÄÄN MUISTISAIRAAN ASUMINEN JA TOIMIJUUS ${ }^{1}$
}

\author{
Leena Viinisalo-Heiskanen: YTT
}

leheiska1@gmail.com

Janus vol. 29 (3) 2021, 297-301

Pysähdytään miettimään tilanteita, joissa olemme pelästyneet, järkyttyneet, tulleet vihaisiksi tai levottomiksi. Olemme metsässä, ehkä marjassa tai sienessä. Olemme kulkeneet ajatuksissamme sinne tänne pysähdellen. Yhtäkkiä havaitsemme, että ympärillä kaikki näyttää samanlaiselta, eikä meillä ole aavistustakaan siitä, mistä suunnasta tulimme eikä myöskään siitä, mihin suuntaan meidän pitäisi lähteä päästäksemme metsästä pois. Huomaamme eksyneemme. Tai ehkä olemme suuressa rakennuksessa, jossa on pitkiä ja sokkeloisia käytäviä. Kaikki ovet ovat suljettuja eikä meillä ole mitään tietoa siitä, missä etsimämme ovi mahtaa olla. Kaikki vastaantulijat ja ohikävelijät ovat tuntemattomia, eikä kenelläkään näytä olevan aikaa pysähtyä meitä neuvomaan pyynnöistämme huolimatta. Tai ehkä huomaamme kadottaneemme jotakin meille tärkeää kuten puhelimen, lompakon, käsilaukun, avaimet tai vaikkapa pankkikortin. Tai ehkä olemme unohtaneet hetkellisesti jotakin, useimmiten nimet.

Nämä äkilliset tilanteet ovat esimerkkejä, joiden avulla voimme yrittää ymmärtää muistisairaan ihmisen tunteita. Alamme ehkä oivaltaa, minkä merkityksen pelko ja levottomuus tuo muistisairaan käyttäytymiseen ja kuinka nopeasti hänen itseluottamuksensa ja itsetuntonsa murskaantuu. (Marshall
2001, 109.) Siihen vaikuttaa myös ympäristön ihmisten suhtautuminen.

Vanha ihminen jää yhteisönsä ulkopuolelle, kun hänestä puhutaan tai häneen katsotaan ikään kuin hän ei olisi paikalla, hänet jätetään huomioimatta, hänen kommenttejaan ei käsitellä, häneltä kielletään oikeus puhumiseen tai hänelle puhutaan kuin lapselle (Askham ym. 2007, 17). Samalla kielletään myös hänen minuutensa ja toimijuutensa. Tästä kuvaavana esimerkkinä on seuraava lainaus japanilaisen tutkijan Towako Katsunon $(2005,206)$ haastatteleman muistisairauden varhaisvaiheessa olevan vanhan ihmisen puheesta:

[Kun] he tietävät, että sinulla on Alzhei-
merin tauti, he yrittävät olla huomioimatta
sinua. Olet vain siellä ja siinä kaikki. Voit
mennä perhetapahtumaan ja kaikki pälpät-
tävät ja pälpättävät sitä ja tätä. He jättävät
sinut yksin, koska he olettavat, että sinä et
tiedä mistä puhut, etkä tiedä mitä tapahtuu.
Voi, kuinka vihasinkaan tätä... Olen edel-
leen ihminen". (Katsuno 2005, 206,211.)

Katsunon mukaan meidän ongelmamme on siinä, että ymmärrämme tämän viestin niin harvoin.

Muistisairaan ihmisen kohtaamista lämpimästi ja arvostavasti pidetään tämän päivän kansalaistaitona. Sitä tuotiin esiin myös syksyllä 2020 vietetyn 
muistiviikon info-tilaisuuksien, kahvila- ja ryhmätoimintojen sekä erilaisten tapahtumien ohjelmaesitteissä. Muistiyhdistykset eri puolilla Suomea ovat järjestäneet näitä erilaisia tapahtumia. (Muistiliitto 2020b.) Muistiviikko järjestetään vuosittain ja sen aloittaa aina Maailman Alzheimer -päivä (World Alzheimer's Day) 21. syyskuuta. Maailman Alzheimer -päivää on vietetty kansainvälisen Alzheimer's Disease International -järjestön johdolla jo vuodesta 1994 ja vuodesta 2012 on vietetty myös Maailman Alzheimer -kuukautta. Tavoitteena on lisätä tietoa muistisairauksista ja samalla vähentää niihin liittyviä ennakkoluuloja ja nostaa esiin, että myös muistisairauden kanssa voi elää omannäköistä ja hyvää elämää. (Muistiliitto 2020a.)

Tutkimukseni (Viinisalo-Heiskanen 2020) kohdistuu iäkkäiden muistisairaiden asumiseen ja toimijuuteen heidän asumisensa murrosvaiheessa. Asumisen murrosvaiheella tarkoitan elämänvaihetta, jolloin asukkaan jokapäiväiseen elämään tulee jokin muutos tai häiriö, kuten esimerkiksi muistisairaus. Tuolloin asumisen itsestäänselvyys ja tavanomaisuus kyseenalaistuvat.

Tarkastelen aihetta asumisen suunnittelun, lehtikeskustelun ja muistisairaiden omasta näkökulmasta. Asumisen suunnittelun ja lehtikeskustelun näkökulmien avulla tavoittelen ymmärrystä siitä, mitä asumisen suunnittelun asiantuntijat muistisairaiden asumisesta ja toimijuudesta puhuivat ja miten julkisessa keskustelussa aihetta käsiteltiin. Vanhojen muistisairaiden ihmisten omien asumis- ja toimijuusnäkemyksien tarkastelulla haluan kääntää ulkopuolisen objektivoivan katseen muistisairaiden omaan subjektiiviseen näkökulmaan.

Iäkkäiden asumisen ratkaisuihin vaikuttavat monet yhteiskunnan tasolla asetetut ikääntymis- ja asumispoliittiset tavoitteet. Asumiseen vaikutetaan lainsäädännön, hallituksen ja ministeriöiden linjausten ja niihin perustuvien suositusten, kehittämisohjelmien sekä -hankkeiden ja rahoittajien kautta. Nämä sääntelyt ja ohjeistukset koskevat erityisesti suunnittelu- ja rakentamisvaihetta. Sen sijaan valmistumisen jälkeistä tilannetta, kuten valmistuneen rakennuksen tuottamaa asumisen laatua, ei kunnolla arvioida (Rappe ym. 2020, 144).

Aikaisemmin muistisairaiden ja muidenkin niin kutsuttuihin erityisryhmiin kuuluvien, kuten esimerkiksi vammaisten, asunnottomien ja huonokuntoisten vanhusten asunnot haluttiin rakentaa eristykseen muusta yhteiskunnasta (Välikangas 2017, 23). Nyt tavoitteena olevan normaaliuden periaatteen mukaan muistisairaiden ja muidenkin erityisryhmiin kuuluvien tulisi voida asua kuten muukin väestö kodikkaissa ja tarkoituksenmukaisissa asunnoissa, joihin on järjestetty tarvittavat tukipalvelut (Asumisen rahoitus- ja kehittämiskeskus 2008, 2) ja tehty mahdolliset erityisratkaisut.

Kunnissa iäkkäiden asumiseen vaikutetaan yhdyskuntasuunnittelulla ja palvelutarjonnalla. Elinkeino- ja liikennepolitiikka ovat usein kaavoituksessa ratkaisevassa asemassa ja iäkkäiden asuminen sijoitetaan sinne, minne jää tilaa. Tästä on seurauksena se, että vaikka tavoitteena olisi edistāä monimuotoisia asuinalueita ja kotona asumisen mah- 
dollisuuksia, asuntojen suunnittelussa ei riittävästi huomioida alueen olemassa olevia palvelurakenteita. Lisäksi suunnittelutyössä keskitytään paljolti rakennuksiin eikä liikkumisen ja palveluiden käytön edellytyksiä oteta riittävästi huomioon. Tuloksena voi olla toimiva ja esteetön rakennus, mutta piha ja lähiympäristö voivat olla esteellisiä ja mielenkiinnottomia. (Rappe ym. 2020, 145.)

Ikääntyneiden asumisen toimenpideohjelmassa ympäristöministeriö (2020) kaipaa iäkkäiden asumisen ja asuinympäristön kehittämisessä asenteiden muutosta. Toimintakyvyltään heikommat tulee nähdä luonnollisena osana yhteiskuntaa ja iäkkäitä tulee tukea asumaan tutussa asuinympäristössä, vaikka palvelutarpeita tulisikin lisää.

Toimijuuden käsitettä on käytetty monilla tieteenaloilla ja sitä koskevat määrittelyt ja merkitykset ovat vaihtelevia. Yhteiskuntatieteissä toimijuus kuuluu peruskäsitteisiin kuten myös toimijuuden tutkiminen. Toimijuutta koskeva mielenkiinto on syntynyt vastapuheena vallitsevalle vanhuuspuheelle, joka korostaa vanhuuteen liitettyä raihnaisuutta, voimattomuutta (Virkola 2014, 41; King \& Calasanti 2009, 38) ja avuttomuutta. Sosiaalisissa käytännöissämme, puhetavoissamme ja kulttuurissamme avuttomuus on nähty kielteisenä ja avun tarve on kääntänyt keskustelun pois avun tarvitsijan toimijuudesta (Tedre 2007, 100; Tedre 2003, 66). Abstraktiin toimijuuteen on sisällytetty ajatus itsenäisestä subjektista, joka kykenee tekemään päätöksiä ja vastaamaan teoistaan kaikissa olosuhteissa. Muistisairauteen sairastunutta ja fyysiset voimansa menettävää vanhaa ihmistä ei näin ollen ole pidetty toimijana eikä myöskään aktiivisena ja valintoja tekevänä kansalaisena. (Anttonen ym. 2009, 37.) Heidän kohdallaan yksilöllinen toimijuus kyseenalaistuu helpommin, koska esimerkiksi asumisvalinnoista puhuttaessa fyysistä ja kognitiivista terveydentilaa käytetään määrittelemään asumistarpeita sekä kykyä tehdä valintoja.

Tutkimuksessani tarkastelen toimijuutta toimijuuden teoreettis-metodologisen viitekehyksen avulla (Jyrkämä 2008, 190). Sen mukaan toimijuus syntyy, muotoutuu ja uudistuu tilanteisesti kuuden, toisistaan erillään pidettävän mutta toisiinsa kytkeytyvän ulottuvuuden avulla. Nämä ulottuvuudet ovat kyetä, osata, haluta, täytyä, tuntea ja voida. Näiden ulottuvuuksien lisäksi pohdin tutkimuksessani, millainen toimijuus tarkentuu muistisairauteen sairastuneen asukkaan arkeen silloin kun arki, sellaisena kuin hän on sen tottunut hahmottamaan, näyttää vähitellen lipuvan häneltä ulottumattomiin. Miten kuvata toimijuutta silloin, kun asukasta ympäristön määrittelemänä pidetään osaamattomana ja kyvyttömänä? Haastattelemieni muistisairaiden toimijuus muistuttaa osittain Marja-Leena Honkasalon $(2008$; 2004) määrittelemää arkista (ks. myös Jokinen 2005), kiinnipitävää, minimaalista tai pientä toimijuutta. Kysymyshän on arjen käytännöissä toteutuvasta ilmiasultaan pienimuotoisesta toiminnasta. Tarvitsin kuitenkin tutkimukseni toimijuuskäsitteeseen sellaista tarkennusta, joka ottaisi huomioon muistisairauden etenevän luonteen. Muistisairauden edetessä sairastuneen taidot taantuvat ja hänen otteensa elämään vähitellen ja usein jo varhaisessa vaiheessa ajoittain herpaantuu. Päädyin tarkentamaan 
toimijuuskäsitteeni jäljellä olevaksi ja korvaavaksi toimijuudeksi. Jäljellä olevalla ja korvaavalla toimijuudella tavoittelen toimijuutta, joka kuvaa muistisairaan ilmiasultaan piiloutuvaa ja murroksessa olevaa toimijuutta, jolla hän pyrkii edelleen vaikuttamaan ja osallistumaan arkeensa.

Tutkimukseni lähtökohtana on toimiva, tunteva, sosiaalisesti rakentuva ja elämäkerrallinen käsitys iäkkäästä ihmisestä. Tarkastelen vanhojen ihmisten toimijuutta suhteessa asuntoon, muistisairauteen, muihin ihmisiin, tilanteisiin, aikaan ja paikkaan sekä erilaisten sosiaalisten toimintakäytäntöjen ja yhteiskunnan rakenteiden kanssa vuorovaikutuksessa muuttuvana ja aina uudelleen rakentuvana. Toimijuudessa on viimesijassa aina kyse valinnasta ja vapaaehtoisesta toiminnasta (Marshall 2005). Näin ollen ymmärrän toimijuuden myös ihmisen vapaan tahdon käyttämisenä ja mahdollisuutena jokapäiväisen elämän tavallisten valintojen ja ratkaisujen tekemiseen. Tärkeää on tunne siitä, että voi itse vaikuttaa omiin asioihinsa. Monet valinnat näyttäytyvät ulkopuoliselle kovin pieninä ja jopa mitättöminä asioina. Asukkaalle ne sen sijaan saattavat olla merkittäviä ja hänen itsemääräämiseen ja toimijuuden tunteeseen vaikuttavia asioita.

Päätän puheenvuoroni esimerkkiin, joka havainnollistaa asukkaalle tärkeää asumiseen liittyvää yksityiskohtaa. Keskustelusta voi erottaa ainakin asukkaan toimijuuden haluta, täytyä, tuntea ja voida ulottuvuudet. Asukkaan nimi on muutettu.

Sosiaalityöntekijänä työskennellessäni ihastelin kerran iäkkään Aunen luo- na asiakaskäynnillä hänen värikkäitä ikkunaverhojaan. "Kyllähän ne tietysti ovat ihan hyvät, mutta minä pidin enemmän niistä hillitymmän värisistä vanhoista verhoista", vastasi Aune. "Tytär tuli käymään lomallaan ja halusi laittaa minulle nämä undet verhot", hän jatkoi. "Olen ajatellut, että kunhan tytär lähtee takaisin Etelä-Suomeen, pyydän naapuria vaihtamaan vanhat verhot takaisin." "No, mutta mitähän tytär mahtaa sanoa, kun hän tulee uudelleen käymään”, kysyin. Aune katsoi minuun nauraen ja totesi: "Hän käy niin harvoin, pari kertaa vuodessa, että voin sanoa, että juuri vaihdatin taas vaihtelun vuoksi vanhat verhot ikkunoihin".

\section{VIITE}

1 Puheenvuoro on Itä-Suomen yliopistossa 25.9.2020 tarkastetun yhteiskuntapolitiikan alaan kuuluvan väitöskirjan lectio praecursoria.

\section{KirjallisuUs}

Anttonen, Anneli \& Valokivi, Heli \& Zechner, Minna (toim.) (2009) Hoiva - tutkimus, politiikka ja arki. Tampere: Vastapaino.

Askham, Janet \& Briggs, Kate \& Norman, Ian \& Redfern, Sally (2007) Care at home for people with dementia: as in a total institution? Ageing and Society 27 (1), 3-24.

Asumisen rahoitus- ja kehittämiskeskus (Ara) (2008) Erityisryhmien asunnot ja asunnontarve - Kysely kunnille 2007, 26.8.2008. Selvityksiä 6. https://www. ara.fi/fi-FI/Tietopankki/Tilastot_ja_selvitykset/Muut_tilastoselvitykset. Luettu 25.11.2020.

Honkasalo, Marja-Liisa (2004) "Elämä on ahasta täällä”. Otteita maailmasta joka ei pidä kiinni. Teoksessa Marja-Liisa Honkasalo, Terhi Utriainen \& Anna Leppo 
(toim.) Arki satuttaa. Kärsimyksiä suomalaisessa nykypäivässä. Tampere:Vastapaino, 51-81.

Honkasalo, Marja-Liisa (2008) Reikä sydämessä. Sairaus pohjoiskarjalaisessa maisemassa. Tampere:Vastapaino.

Jokinen, Eeva (2005) Aikuisten arki. Helsinki: Gaudeamus.

Jyrkämä, Jyrki (2008) Toimijuus, ikääntyminen ja arkielämä - hahmottelua teoreettis-metodologiseksi viitekehykseksi. Gerontologia 22 (4), 190-203.

Katsuno, Towako (2005) Dementia from the inside: how people with earlystage dementia evaluate their quality of life. Ageing and Society 25 (2), 197-214. https://doi.org/10.1017/ S0144686X0400279X

King, Neal \& Calasanti, Toni (2009) Aging agents: social gerontologists' imputations to old people. International Journal of Sociology and Social Policy 29 (1-2), 38-48. https://doi. org/10.1108/01443330910934709

Marshall, Mary (2001) New Trends and Dilemmas in Working with People with Dementia and their Carers. Teoksessa Alan Chapman \& Mary Marshall (toim.) Dementia: New Skills for Social Workers. 3. painos. London: Jessica Kingsley, 3-15. (1. painos 1993).

Marshall, Victor (2005) Agency, event, and structure at the end of life course. Towards an interdisciplinary perspective on the life course. Advances in Life Course Research 10, 57-91. https://doi. org/10.1016/S1040-2608(05)10002-1

Muistiliitto (2020a) Muistiviikko 2020 https://www.muistiliitto.fi/fi/tuki-japalvelut/muistiyhdistys-lahellasi/tapahtumat. Luettu 11.9.2020.

Muistiliitto (2020b) Tapahtumat. https:// www.muistiliitto.fi/fi/tuki-ja-palvelut/ muistiyhdistys-lahellasi/tapahtumat. Luettu 11.9.2020.
Rappe, Erja \& Rajaniemi, Jere \& Topo, Päivi (2020) Hyvä asuminen muistisairaana. Ikäinstituutti. Gerontologia 34 (29), 135-154. https://doi.org/10.23989/gerontologia.84947

Tedre, Silva (2003) Hoiva ja vanhuus. Teoksessa Marjatta Marin \& Sinikka Hakonen (toim.) Seniori- ja vanhustyö arjen kulttuureissa. Jyväskylä: PS-kustannus, 57-71. Tedre, Silva (2007) Vanhuuden vahvat ja avuttomat. Teoksessa Marjaana Seppänen, Antti Karisto \& Teppo Kröger (toim.) Vanhuus ja sosiaalityö. Juva: WS Bookwell Oy, 95-119.

Viinisalo-Heiskanen, Leena (2020) Kun oma tupa ja oma lupa haurastuvat. Tutkimus iäkkäiden muistisairaiden asumisesta ja toimijuudesta. Publications of the University of Eastern Finland. Dissertations in Social Sciences and Business Studies No 231. Joensuu: University of Eastern Finland.

Virkola, Elisa (2014) Toimijuutta, refleksiivisyyttä ja neuvotteluja - muistisairaus yksiasuvan naisen arjessa. Jyväskylä Studies in Education, Psychology and Social Research 491. Jyväskylä: Jyväskylän yliopisto.

Välikangas, Katariina (2017) Kuntien toiminta ikääntyneiden kotona asumisen tukemisessa ja elinympäristöjen kehittämisessä. Teoksessa Raija Hynynen (toim.) Ikääntyneiden asumistarpeisiin varautuminen kunnissa. Ympäristöministeriön raportteja 4. https://julkaisut.valtioneuvosto.fi/bitstream/ handle/10024/79772/YMra_4_2017. pdf?sequence $=1 \&$ is Allowed $=y . \quad$ Luettu 19.9.2019.

Ympäristöministeriö (2020) Ikääntyneiden asumisen toimenpideohjelma vuosille 2020-2022. https://ym.fi/ikaantyneiden-asuminen. Luettu 11.9.2020. 